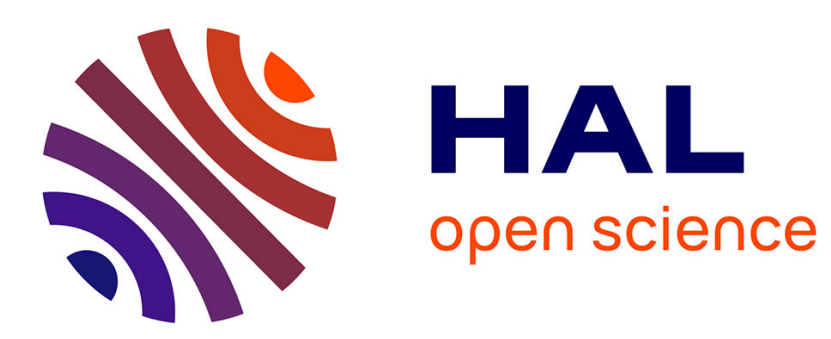

\title{
A Web service for controlling the quality of measurements of global solar irradiation
}

Michael Geiger, Lamissa Diabaté, Lionel Ménard, Lucien Wald

\section{To cite this version:}

Michael Geiger, Lamissa Diabaté, Lionel Ménard, Lucien Wald. A Web service for controlling the quality of measurements of global solar irradiation. Solar Energy, 2002, 73 (6), pp.475-480. hal00361370

\section{HAL Id: hal-00361370 \\ https://hal.science/hal-00361370}

Submitted on 13 Feb 2009

HAL is a multi-disciplinary open access archive for the deposit and dissemination of scientific research documents, whether they are published or not. The documents may come from teaching and research institutions in France or abroad, or from public or private research centers.
L'archive ouverte pluridisciplinaire HAL, est destinée au dépôt et à la diffusion de documents scientifiques de niveau recherche, publiés ou non, émanant des établissements d'enseignement et de recherche français ou étrangers, des laboratoires publics ou privés. 


\title{
A WEB SERVICE FOR CONTROLLING THE QUALITY OF MEASUREMENTS OF GLOBAL SOLAR IRRADIATION
}

\author{
Geiger M. (1), Diabaté L. (2), Ménard L. (1), Wald L. (1) \\ (1) Groupe Télédétection \& Modélisation, Centre d'Energétique, Ecole des Mines de Paris, BP 207, \\ 06904 Sophia Antipolis cedex, France. Tel.: +33 (0) 4.93.95.74.49 Fax: +33 (0) 4.93.95.75.35. \\ Corresponding author: L. Wald, e-mail : lucien.wald@ensmp.fr. \\ (2) UFAE / GCMI, BP E4018, 410, avenue Van Vollenhoven, Bamako, Mali.
}

Keywords: solar radiation, quality assessment, Internet

\begin{abstract}
$\underline{\text { ABSTRACT }}$
The control of the quality of irradiation data is often a prerequisite to their further processing. Though data are usually controlled by meteorological offices, the sources are so numerous that the user often faces time-series of measurements containing questionable values. As customers of irradiation data, we established our own procedures to screen time-series of measurements. Since this problem of quality control is of concern to many researchers and engineers and since it is often a lengthy and tedious task, we decided to make this screening procedure available to everyone as a web service. This service is the purpose of this paper. The objective is not to perform a precise and fine control, an objective out of reach without details on the site and instruments, but to perform a likelihood control of the data and to check their plausibility. This is achieved by comparing observations with some expectations based upon the extraterrestrial irradiation and a simulation of the irradiation for clear skies. This service is available to everyone on the Web site www.helioclim.net. It offers a very convenient means to check time-series of irradiation: data are input in a HTML page by a copy and paste procedure and the return is also a HTML page that can be analyzed in details for the data flagged as suspicious.
\end{abstract}




\section{Controlling the quality of irradiation measurements}

The measurements of solar global radiation on the ground level are made primarily with pyranometers. These hemispherically sensitive sensors measure the downward solar radiation flux on a horizontal surface during a given time. This energy is called irradiation and is usually expressed in $\mathrm{Wh} \mathrm{m}$ or $\mathrm{J} \mathrm{cm}^{-2}$. The properties of pyranometers under concern when evaluating the accuracy and quality of irradiation measurements are: sensitivity, stability, response time, cosine response, azimuth response, linearity, temperature response, and spectral response (ESRA 2000; ISO-9060 1990). The deviations are primarily caused by the directional sensitivity of the individual receiver surfaces and by effects of the glass dome which covers the upward-facing sensor. Some errors that appear are due to a dust layer or snow or ice on the dome. Other errors may occur from inaccurate horizontal adjustment of the receiver surface, moisture inside the dome, etc. Achievable relative uncertainties at the 95 per cent confidence level are about 3, 8 and 20 per cent for operational pyranometers of high, good and moderate quality in case of hourly sums. In case of daily sums, relative uncertainties of 2, 5 and 10 per cent can be achieved (WMO, 1981).

When taking observations and processing their results, errors may be made which should be detected and, as far as possible, corrected. A reliable estimate of errors is only possible by the final user, when information about the pyranometer is available. This is seldom the case. The irradiation measurements should be checked in two stages: technical control, and quality control. When observations are acquired from national meteorological services, it is usually assumed that the measurements first went through a technical control by these services. The process of quality control is distinct from technical control. Not only is the correctness of arithmetic calculations checked but also agreement of every radiation parameter with the sun elevation and other parameters. The quality control of radiometric observations is guided by basic physical principles which determine the relations between individual radiation parameters; it may also take into account statistical knowledge on the spatial and temporal variability of these parameters (ESRA 2000).

Quality control may be a lengthy task. Most often, customers do not have the necessary information to perform a precise and fine control. Accordingly, they are trusting the procedures used by the 
meteorological offices and are ready to use the data in confidence. However, the sources of information are very numerous and do not exhibit the same reliability. It often happens that the user faces time-series of measurements containing questionable values. The reasons are numerous, ranging from non-standard values for the absence of measurements (e.g., 0 instead of -999) to typing errors if the processing chain of measurements is not entirely digital.

As customers of irradiation data, we felt the need to establish our own procedures to screen time-series of measurements. The objective is not to perform a precise and fine control, an objective out of reach without details on the site and instruments, but to flag the data that are obviously questionable. Examples are null values when -999 is expected, values much larger than the extraterrestrial irradiation or positive values when the sun is well below the horizon. The aim of these procedures is to perform a likelihood control of the data and to check the plausibility of the measurements. This is performed by comparing observations with those expected. Since this problem of quality control is of concern to many researchers and engineers, we decided to make this screening procedure available to everyone as a web service. This service is the purpose of this paper.

\section{Quality control procedures}

The quality control procedure adopted in the present paper meets the guidelines of the World Meteorological Organisation (WMO 1981) and implements some of the procedures used in the construction of the European Solar Radiation Atlas (ESRA 2000). The procedure applies to daily or hourly sums of global irradiation. It applies to individual values or time-series. Because of the limited amount of information, the procedure is restricted to the analysis of each measurement with respect to the extraterrestrial irradiation and the extreme that can be expected for this particular instant. The procedure is exactly the same for daily and hourly irradiation. 


\subsection{Quality control for maximum values of daily sums of global solar irradiation}

First of all, each observed daily sum $G_{\mathrm{d}}$ (resp. hourly sum $G_{\mathrm{h}}$ ) should be less than the daily (resp. hourly) extraterrestrial irradiation received by a horizontal plane located at the same geographical co-ordinates. Otherwise it is flagged as questionable. This is the first condition.

In addition, the daily irradiation should only exceed by a small amount the daily irradiation $G_{\mathrm{cd}}$ (resp. hourly irradiation $G_{\mathrm{ch}}$ ) likely to be observed under exceptionally clear skies with a high atmospheric transparency. The clear sky irradiation $G_{\mathrm{cd}}\left(\operatorname{resp} . G_{\mathrm{ch}}\right)$ is assessed by means of the ESRA model for clear sky. This model is based upon parameterization formula by Kasten (in ESRA 1984 and Kasten 1996) and has been detailed in Rigollier et al. (2000). Corrections were brought to this model as proposed by Remund, Page (2002). The formula for the Rayleigh optical thickness in Rigollier et al. behaves incorrectly with terrain altitude in the original model. This was not evidenced in the paper of Rigollier $e t$ $a l$. because the sites used for validation have altitudes less than $500 \mathrm{~m}$. Europe as a whole offers a few areas of altitudes larger than $1000 \mathrm{~m}$. Other continents such as Africa or Asia have large areas of larger altitude and such corrections are necessary. Using the notations of Rigollier et al., the beam transmittance under cloudless skies is given by their Equation 2:

$$
\exp \left[-0.8662 T_{\mathrm{L}}(A M 2) m \delta_{\mathrm{R}}(m)\right]
$$

where $T_{\mathrm{L}}(A M 2)$ is the Linke turbidity factor for an air mass equal to $2, m$ is the relative optical air mass and $\delta_{\mathrm{R}}(m)$ is the integral Rayleigh optical thickness. The air mass $m$ is given by (their Equation \# 3):

$$
m\left(\gamma_{S}\right)=\left(p / p_{0}\right) /\left[\sin \gamma_{S}+0.50572\left(\gamma_{S}+6.07995\right)^{-1.6364}\right]
$$

where $\gamma_{s}$ is the solar altitude angle, possibly corrected for refraction effects, and the station height correction is given by their Equation \# 4: $\left(p / p_{0}\right)=\exp \left(-z / z_{\mathrm{h}}\right)$, where $z$ is the site elevation and $z_{\mathrm{h}}$ is the scale height of the Rayleigh atmosphere near the Earth surface, equal to 8434.5 meters. The parameterization of the Rayleigh optical thickness is given by their Equation \# 7:

$$
\begin{aligned}
& \text { if } m \leq 20,\left(\gamma_{\mathrm{S}} \geq 1.9^{\circ}\right), 1 / \delta_{\mathrm{R}}(m)=6.6296+1.7513 m-0.1202 m^{2}+0.0065 m^{3}-0.00013 m^{4} \\
& \text { if } m>20,\left(\gamma_{\mathrm{S}}<1.9^{\circ}\right), 1 / \delta_{\mathrm{R}}(m)=10.4+0.718 m
\end{aligned}
$$


In the modified ESRA model, the equations become:

$$
m\left(\gamma_{\mathrm{S}}\right)=1 /\left[\sin \gamma_{\mathrm{S}}+0.50572\left(\gamma_{\mathrm{S}}+6.07995\right)^{-1.6364}\right]
$$

Let $c o r r_{-} \delta_{\mathrm{R}}\left(p / p_{0}\right)$ be the correction of the integral Rayleigh optical thickness due to the elevation of the site. Remund, Page determined this function for two values of $\left(p / p_{0}\right)$ :

$$
\begin{aligned}
& c o r r_{-} \delta_{\mathrm{R}}(0.75)=1.248174-0.011997 m\left(\gamma_{\mathrm{S}}\right)+0.00037 m^{2}\left(\gamma_{\mathrm{S}}\right) \\
& c o r r_{-} \delta_{\mathrm{R}}(0.50)=1.68219-0.03059 m\left(\gamma_{\mathrm{S}}\right)+0.00089 m^{2}\left(\gamma_{\mathrm{S}}\right)
\end{aligned}
$$

Given that $c o r r_{-} \delta_{\mathrm{R}}(1)=1$ and assuming that $c o r r_{-} \delta_{\mathrm{R}}\left(p / p_{0}\right)=c o r r_{-} \delta_{\mathrm{R}}(0.5)$ for $\left(p / p_{0}\right)<0.5, c o r r_{-} \delta_{\mathrm{R}}\left(p / p_{0}\right)$ can be determined for any $\left(p / p_{0}\right)$ by piecewise linear interpolation. The integral Rayleigh optical thickness is thus given by:

$$
\begin{aligned}
& \text { if } m \leq 20,\left(\gamma_{S} \geq 1.9^{\circ}\right) \\
& 1 / \delta_{\mathrm{R}}(m)=\text { corr_ } \delta_{\mathrm{R}}\left(p / p_{0}\right) /\left[6.625928+1.92969 m-0.170073 m^{2}+0.011517 m^{3}-0.000285 m^{4}\right] \\
& \text { if } m>20,\left(\gamma_{S}<1.9^{\circ}\right), 1 / \delta_{\mathrm{R}}(m)=10.4+0.718 m\left(p / p_{0}\right)
\end{aligned}
$$

This revised model can be executed via the SoDa web site (see on-line at http://www.soda-is.com). In the quality assessment procedure, each observed value $G_{\mathrm{d}}\left(\right.$ resp. $\left.G_{\mathrm{h}}\right)$ is compared to the corresponding clear sky value $G_{\text {cd }}\left(\right.$ resp. $\left.G_{\text {ch }}\right)$. The second condition is that $G_{\mathrm{d}}$ should be less than $\left(1.1 G_{\mathrm{cd}}\right)$. Otherwise the observation for this day is flagged as questionable.

The clear-sky model makes use of the Linke turbidity factor, a parameter quantifying the atmospheric visibility (aerosol plus water vapor) under clear skies. Values of this factor are available on climatological basis (Angles et al. 1998, 1999; the SoDa web site: http://www.soda-is.com). It varies from site to site and from month to month. Typical values can be found in WMO (1981). A value of 1 stands for very optically clean atmosphere and may be adopted to control the upper limit of the daily irradiation. It is recommended to perform this test twice with two different Linke turbidity factors (e.g., 1 and 3 or 2 and 4 ) to assess the sensitivity of the results to this factor. 


\subsection{Quality control for minimum values of daily sums of global solar irradiation}

The third condition to be fulfilled is that the daily sum $G_{\mathrm{d}}$ (resp. hourly sum $G_{\mathrm{h}}$ ) is greater than a minimum value expected in continuous overcast conditions. This is equivalent to saying that the clearness index $K T_{\mathrm{d}}$ (resp. $K T_{\mathrm{h}}$ ) should be greater than a minimum value. This minimum value was set up according to the analysis of the collected data and to the minima of $K T_{\mathrm{d}}\left(\right.$ resp. $\left.K T_{\mathrm{h}}\right)$ found in the last and previous editions of the European solar radiation atlas (ESRA 1984, 2000). Accordingly, the smallest acceptable value for $K T_{\mathrm{d}}$ and $K T_{\mathrm{h}}$ is 0.03 , which represents a heavily overcast sky.

\subsection{The case of very high latitude sites}

Special attention was paid to the observed solar irradiation data for the sites at very high latitudes, when the elevation of the sun above horizon at noon is less than $2^{\circ}$. When the extraterrestrial irradiation on the horizontal plane $G_{0 \mathrm{~d}}$ is greater than $1 \mathrm{~J} \mathrm{~cm}^{-2}\left(2.78 \mathrm{Wh} \mathrm{m}^{-2}\right)$, the upper acceptance limit is set to $\left(2 G_{\mathrm{cd}}\right)$ and the lower acceptance limit is set to $\left(0.015 G_{0 \mathrm{~d}}\right)$. When the extraterrestrial irradiation is less than $1 \mathrm{~J} \mathrm{~cm}^{-2}$, values of $G_{\mathrm{d}}$ are still accepted if they are less than $10 \mathrm{~J} \mathrm{~cm}^{-2}\left(27.78 \mathrm{Wh} \mathrm{m}^{-2}\right)$ and no minimum value is set. The reasons for doing this are that on the one hand measuring instruments have an optimum precision of 5 $\mathrm{W} \mathrm{m}^{-2}$ and that on the other hand atmospheric phenomena like refraction are present (ESRA, 2000).

\section{Web service}

The quality control procedure is part of an on-going effort of the Group 'Télédétection \& Modélisation' of the Ecole des Mines de Paris / Armines to provide free of charge valuable tools and information to the solar radiation community through the most known and used media, namely the world wide web. The web server HelioClim (http://www.helioclim.net) hosts the quality control procedure and other solar radiation oriented sizing tools. It is built by using open source software. Apart from the fact that those softwares can be used free of charge, they are rated among the most used, reliable, fast and secure tools available on the market (Netcraft 2001). Installed on a Linux box an Apache web server is delivering result by the mean of CGI (Common Gateway Interface) based scripts (see references on 
tools Linux (2001) and Apache (2001)). The interesting feature of the CGI-based quality control procedure is the re-use of source code (mainly $\mathrm{C}$ code), procedures and libraries already written, used and validated by the scientific community in various projects like ESRA (2000), Helioserve (Angles et al. 1998) and SoDa (Wald 2000; Wald et al. 2002). The HelioClim web site use also extensively MySQL a relational database to store, extract and manipulate solar radiation parameters and PHP, a server-side, cross-platform, HTML embedded scripting language (see references on tools MySQL and PHP).

The user interface has been kept simple for a maximum reliability over the network bandwidth. The user is requested to provide information to compute the quality control procedure: geographical coordinates, elevation and dates (if single value). Detailed help HTML pages are available to better understand and correctly fill the forms of each quality control procedure. Documents explaining the algorithm used in the calculation and references to articles, web site of interest and publications on solar radiation topic are also provided.

The quality control procedure has been divided in four HTML documents:

- Daily irradiation for a single day. One value is to be examined,

- Daily irradiation for several days. Several daily values spread over several months and years can be analysed in one click,

- Hourly irradiation for a single hour. One value is analysed,

- Hourly irradiation for several hours. Several hourly values spread over several days, months and years can be tested in one click.

Simple forms are used inside the HTML document allowing a one-click per page result. Figure 1 exhibits a snapshot of the input and output forms for screening a single day. The service was tested by the means of several time-series of hourly and daily irradiations available in the CD-ROM of the European solar radiation atlas (ESRA 2000).

\section{Example}

This web service was used to perform a quality screening of time-series of daily irradiation for the period 1994-1998 and for sites in Africa. Data were provided by the networks belonging to the World Meteorological Organization. These data are prominent in constructing global maps of the Linke 
turbidity factor within the SoDa project (Wald 2000) as well as in assessing the accuracy of the method Heliosat-II, aimed at retrieving solar irradiations from an appropriate processing of satellite data (Rigollier, Wald 1999; Lefèvre et al. 2002). Hence, it is important that these data are properly screened.

Figure 2 exhibits an extract of the HTML page containing the results of the test. The site under concern is Casablanca (Senegal). Here are only reported three months of 1994 and nine of 1998 for illustration. Each line represents a month. For each line, there are 31 cells, one per day. The character "V" stands for "verified" and means that the value is OK with respect to the procedure. The days not passing the test are flagged with a number taking values $10,11,12$ or 21 to 24 .

The number 10 means that the daily irradiation is greater than the extraterrestrial value. An example is the day 24 November 1994. When clicking on a cell flagged as incorrect, another page appears, similar to Figure $1 \mathrm{~b}$. This new page gives the observed irradiation for this instant (day or hour), the extraterrestrial irradiation, the irradiation for clear sky and the solar elevation at noon. It permits to see how large is the discrepancy between the observed value and the threshold under concern. Values may be rehabilitated or discarded.

In August 1998, two days (13 and 21) exhibit values that are well exceeding the expected value for very clear skies. Here, the Linke turbidity factor was set to 2 , a value well below the typical values for this site. It follows that the irradiations for these two days are overestimated and should be rejected. They are flagged with the number 11 .

Missing values are set to 0. Such days (e.g., 31 November 1994, 29, 30 and 31 February 1998) are flagged with the number 12 .

The other flagging values 21 to 24 are used for the tests for low solar elevations at noon.

\section{Conclusion}

This web service is available to everyone on a free basis. Data are input in the HTML page by a copy and paste procedure. A full year of daily values can be pasted and processed in one click. The return is also a HTML page that can be saved and further processed if necessary. The worst errors are 
identified, that is the unlikely values are flagged. This service calls upon up-to-date algorithms that have proven quality. They may be changed as progresses are made. This service offers a very convenient means to users to check time-series of irradiation without writing and testing the procedures themselves.

\section{Acknowledgements}

The content of the present paper was influenced by the chapter II of the ESRA handbook. Fruitful discussions were held with John Page (Sheffield, United Kingdom) and Gerhard Czeplak (Hamburg, Germany). The program Leonardo of the Commission of the European Communities offered a grant for the stay of Michael Geiger in France. This work was also partly supported by the Commission under Contract Number IST-1999-12245.

\section{References}

Angles J., Ménard L., Bauer O., Wald L. (1998) A Web server for accessing a database on solar radiation parameters. In Proceedings of the Earth Observation \& Geo-Spatial Web and Internet Workshop '98, Josef Strobl \& Clive Best (Eds), Salzburger Geographische Materialien, Universität Salzburg, Salzburg, Austria, Heft 27, pp. 33-34:

http://www.sbg.ac.at/geo/eogeo/authors/angles/angles.html.

Angles J., Ménard L., Bauer O., Rigollier C., Wald L. (1999) A climatological database of the Linke turbidity factor. In Proceedings of the ISES Solar World Congress 1999, Jerusalem, Israel, July 4-9, 1999, volume I, pp 432-434.

Apache (2001) The Apache Software Foundation: http://www.apache.org.

ESRA (1984) European Solar Radiation Atlas. Second Improved and Extended Edition, Vols. I and II. (1984) W. Palz (Ed.). Commission of the European Communities, DG Science, Research and Development, Report No. EUR 9344, Brussels.

ESRA (2000) European Solar Radiation Atlas, includ. CD-ROM. Edited by J. Greif, K. Scharmer. Scientific advisors: R. Dogniaux, J. K. Page. Authors : L. Wald, M. Albuisson, G. Czeplak, B. Bourges, R. Aguiar, H. Lund, A. Joukoff, U. Terzenbach, H. G. Beyer, E. P. Borisenko. Published for the Commission of the European Communities by Presses de l'Ecole, Ecole des Mines de Paris, France. http://www.helioclim.net/esra/ 
ISO 9060 (1990) Solar energy - specification and classification of instruments for measuring hemispherical solar and direct solar radiation. Instrumental standard ISO 9060. International Organisation for Standardization (ISO), Geneva, Switzerland.

Kasten F. (1996) The Linke turbidity factor based on improved values of the integral Rayleigh optical thickness. Solar Energy, 56, 239-244.

Lefèvre M., Rigollier C., Cros S., Albuisson M., Wald L., 2002, A shortwave radiation database to support GODAE-related activities. Proceedings of the International Symposium "En route to GODAE", 13-15 June 2002, Biarritz, France. Published by CNES, Toulouse, France, 2002, pp. $157-$ 158.

Linux (2001) Linux On line: http://www.linux.org.

MySQL: http://www.mysql.org

Netcraft (2001) Netcraft web server survey: http://www.netcraft.com/survey/ Internet Research Reports: http://www.securityspace.com/s_survey/data/index.html.

PHP Hypertext Preprocessor: http://www.php.net.

Remund J., Page J. (2002). Advanced parameters. Chain of algorithms. Part I: shortwave radiation. Report to the European Commission, SoDa project IST-1999-12245, 13 p. Available on-line at http://www.soda-is.com.

Rigollier C., Bauer O., Wald L. (2000) On the clear sky model of the $4^{\text {th }}$ European Solar Atlas with respect to Heliosat method. Solar Energy, 68 (1), 33-48.

Rigollier C., Wald L. (1999) The HelioClim Project: from satellite images to solar radiation maps. In Proceedings of the ISES Solar World Congress 1999, Jerusalem, Israel, July 4-9, 1999, volume I, pp 427-431.

Wald L. (2000) SoDa: a project for the integration and exploitation of networked solar radiation databases. In Proceedings of the European Geophysical Society Meeting, XXV General Assembly, Nice, France, 25-29 April 2000 (CD-ROM).

Wald L., Albuisson M., Best C., Delamare C., Dumortier D., Gaboardi E., Hammer A., Heinemann D., Kift R., Kunz S., Lefèvre M., Leroy S., Martinoli M., Ménard L., Page J., Prager T., Ratto C., Reise C., Remund J., Rimoczi-Paal A., Van der Goot E., Vanroy F., and Webb A. (2002) SoDa: a project for the integration and exploitation of networked solar radiation databases. In: Environmental Communication in the Information Society, W. Pillmann, K. Tochtermann Eds, Part 2, pp. 713-720. Published by the International Society for Environmental Protection, Vienna, Austria. World Meteorological Organization, WMO (1981). Meteorological aspects of the utilization of solar radiation as an energy source. Annex: World maps of relative global radiation. Technical Note No. 172, WMO-No. 557, Geneva, Switzerland, 298 pp. 


\section{FIGURE CAPTIONS}

Figure 1. Screening daily irradiation. Left) the form for screening a single day. Right) the screening results.

Figure 2. An example of the HTML page containing the results (see text for more explanations). 


\begin{tabular}{|c|c|c|c|c|c|c|c|c|}
\hline \multicolumn{9}{|l|}{ Quality Control } \\
\hline daily radiation data section & hourly radiatior & n data section & \multirow{3}{*}{\multicolumn{6}{|c|}{$\begin{array}{l}\text { Test results : } \\
\text { coordinates: } \\
\text { latitude: } 33.57 \\
\text { longitude }:-7.67 \\
\text { station height: } 62.0 \\
\text { time : year : } 1994 \text { month : } 12 \text { day : } 1\end{array}$}} \\
\hline \multicolumn{3}{|c|}{$\begin{array}{l}\text { Daily Radiation Data Section } \\
\text { To get your daily irradiation data tested, fill in the following form, please }\end{array}$} & & & & & & \\
\hline \multicolumn{3}{|c|}{ Latitude of station (decimal deg.) ? 33.57} & & & & & & 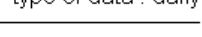 \\
\hline \multicolumn{2}{|c|}{ Longitude of station (decimal deg.)? $7-7.67$} & \multirow[t]{2}{*}{ heilp } & \multicolumn{5}{|c|}{ error number $\longdiv { \text { measured } } \mid$ extraterrestial model's value sun's noonelevation } & \\
\hline & & & 0 & 2700.00 & 5133.25 & 3567.80 & \multirow{2}{*}{34.61} & \\
\hline Linke Turbidity (AM2)? & 3 & help & & \\
\hline and Model? & $0.0=$ & help & & & & & & \\
\hline Year? & \begin{tabular}{|l}
1994 \\
12
\end{tabular} & help & \multicolumn{5}{|c|}{ error description : } & \\
\hline Day? & 1 & \multirow[b]{2}{*}{ help } & \multirow{2}{*}{\multicolumn{5}{|c|}{$\begin{array}{l}\text { - } 0: \text { no error : verified ok! } \\
\text { - error class : no error }\end{array}$}} & \\
\hline \multicolumn{2}{|c|}{$\begin{array}{l}\text { Daily global irradiation data has to be submitted here: } \\
\text { Value for this day }(\text { Wh/m2)? }\end{array}$} & & & & & & & \\
\hline \begin{tabular}{l|l|l|l|l|l} 
Process Data & Reset
\end{tabular} & & & & & & & & \\
\hline
\end{tabular}

Figure 1. Screening daily irradiation. Left) the form for screening a single day. Right) the screening results. 
test for a station's daily solar radiation data :

coordinates :

latitude : 33.57

longitude : -7.67

station height : 62.0

\begin{tabular}{|c|c|c|c|c|c|c|c|c|c|c|c|c|c|c|c|c|c|c|c|c|c|c|c|c|c|c|c|c|c|c|c|}
\hline 1994:10 & $\mathrm{V}$ & $\mathrm{V}$ & $\mathrm{V}$ & $\mathrm{V}$ & $\mathrm{V}$ & $\mathrm{V}$ & V & $\mathrm{V}$ & V & $\mathrm{V}$ & $\mathrm{V}$ & $\mathrm{V}$ & $\mathrm{V}$ & $\mathrm{V}$ & $\mathrm{V}$ & $\mathrm{V}$ & V & V & $\mathrm{V}$ & $\overline{\mathrm{V}}$ & V & V & $\mathrm{V}$ & $\mathrm{V}$ & $\mathrm{V}$ & V & $\mathrm{V}$ & V & $\mathrm{V}$ & $\mathrm{V}$ & $\mathrm{V}$ \\
\hline$: 11$ & $\mathrm{~V}$ & $\mathrm{~V}$ & $\mathrm{~V}$ & $\mathrm{~V}$ & $\mathrm{~V}$ & $\mathrm{~V}$ & $\mathrm{~V}$ & $\mathrm{~V}$ & $\mathrm{~V}$ & $\mathrm{~V}$ & $\mathrm{~V}$ & $\mathrm{~V}$ & $\mathrm{~V}$ & $\mathrm{~V}$ & $\mathrm{~V}$ & $\mathrm{~V}$ & $\mathrm{~V}$ & $\mathrm{~V}$ & $\mathrm{~V}$ & $\mathrm{~V}$ & $\mathrm{~V}$ & $\mathrm{~V}$ & $\mathrm{~V}$ & $\underline{10}$ & $\mathrm{~V}$ & $\mathrm{~V}$ & $\mathrm{~V}$ & $\mathrm{~V}$ & $\mathrm{~V}$ & $\mathrm{~V}$ & 12 \\
\hline 1994:12 & $\mathrm{V}$ & $\mathrm{V}$ & V & $\mathrm{V}$ & $\mathrm{V}$ & $\mathrm{V}$ & $\mathrm{V}$ & $\mathrm{V}$ & $\mathrm{V}$ & $\mathrm{V}$ & $\mathrm{V}$ & $\mathrm{V}$ & $\mathrm{V}$ & $\mathrm{V}$ & $\mathrm{V}$ & $\mathrm{V}$ & $\mathrm{V}$ & $\mathrm{V}$ & $\mathrm{V}$ & $\mathrm{V}$ & $\mathrm{V}$ & $\mathrm{V}$ & $\mathrm{V}$ & $\overline{\mathrm{V}}$ & $\mathrm{V}$ & $\mathrm{V}$ & $\mathrm{V}$ & $\mathrm{V}$ & $\mathrm{V}$ & $\mathrm{V}$ & $\mathrm{V}$ \\
\hline \begin{tabular}{|l|} 
1998:1 \\
\end{tabular} & $\mathrm{V}$ & $\mathrm{V}$ & $\mathrm{V}$ & $\mathrm{V}$ & $\mathrm{V}$ & $\mathrm{V}$ & $\mathrm{V}$ & $\mathrm{V}$ & $\mathrm{V}$ & $\mathrm{V}$ & $\mathrm{V}$ & $\mathrm{V}$ & $\mathrm{V}$ & $\mathrm{V}$ & $\mathrm{V}$ & $\mathrm{V}$ & $\mathrm{V}$ & $\mathrm{V}$ & $\mathrm{V}$ & $\mathrm{V}$ & $\mathrm{V}$ & $\mathrm{V}$ & $\mathrm{V}$ & $\mathrm{V}$ & $\mathrm{V}$ & $\mathrm{V}$ & $\mathrm{V}$ & $\mathrm{V}$ & $\mathrm{V}$ & $\mathrm{V}$ & $\mathrm{V}$ \\
\hline 1998:2 & $\mathrm{V}$ & $\mathrm{V}$ & $\mathrm{V}$ & $\mathrm{V}$ & $\mathrm{V}$ & $\mathrm{V}$ & $\mathrm{V}$ & $\mathrm{V}$ & $\mathrm{V}$ & $\mathrm{V}$ & $\mathrm{V}$ & $\mathrm{V}$ & $\mathrm{V}$ & $\mathrm{V}$ & $\mathrm{V}$ & $\mathrm{V}$ & $\mathrm{V}$ & $\mathrm{V}$ & $\mathrm{V}$ & $\mathrm{V}$ & $\mathrm{V}$ & $\mathrm{V}$ & $\mathrm{V}$ & $\mathrm{V}$ & $\mathrm{V}$ & $\mathrm{V}$ & $\mathrm{V}$ & $\mathrm{V}$ & 12 & 12 & 12 \\
\hline 1998:3 & $\mathrm{V}$ & $\mathrm{V}$ & $\mathrm{V}$ & $\mathrm{V}$ & $\mathrm{V}$ & $\mathrm{V}$ & $\mathrm{V}$ & $\mathrm{V}$ & $\mathrm{V}$ & $\mathrm{V}$ & $\mathrm{V}$ & $\mathrm{V}$ & $\mathrm{V}$ & $\mathrm{V}$ & $\mathrm{V}$ & $\mathrm{V}$ & $\mathrm{V}$ & $\mathrm{V}$ & $\mathrm{V}$ & $\mathrm{V}$ & $\mathrm{V}$ & $\mathrm{V}$ & $\mathrm{V}$ & $\mathrm{V}$ & $\mathrm{V}$ & $\mathrm{V}$ & $\mathrm{V}$ & $\mathrm{V}$ & $\mathrm{V}$ & $\mathrm{V}$ & $\mathrm{V}$ \\
\hline 1998:4 & $\mathrm{V}$ & $\mathrm{V}$ & $\mathrm{V}$ & $\mathrm{V}$ & $\mathrm{V}$ & $\mathrm{V}$ & $\mathrm{V}$ & $\mathrm{V}$ & $\mathrm{V}$ & $\mathrm{V}$ & $\mathrm{V}$ & $\mathrm{V}$ & $\mathrm{V}$ & $\mathrm{V}$ & $\mathrm{V}$ & $\mathrm{V}$ & $\mathrm{V}$ & $\mathrm{V}$ & $\mathrm{V}$ & $\mathrm{V}$ & $\mathrm{V}$ & $\mathrm{V}$ & $\mathrm{V}$ & $\mathrm{V}$ & $\mathrm{V}$ & $\mathrm{V}$ & $\mathrm{V}$ & $\mathrm{V}$ & $\mathrm{V}$ & $\mathrm{V}$ & 12 \\
\hline \begin{tabular}{|l|}
$1998: 5$ \\
\end{tabular} & 12 & 12 & 12 & 12 & 12 & 12 & 12 & $\underline{12}$ & 12 & $\underline{12}$ & 12 & 12 & 12 & 12 & 12 & 12 & $\underline{12}$ & 12 & 12 & 12 & 12 & 12 & 12 & $\underline{12}$ & $\underline{12}$ & 12 & 12 & $\underline{12}$ & 12 & $\underline{12}$ & 12 \\
\hline 1998:6 & $\mathrm{V}$ & $\mathrm{V}$ & $\mathrm{V}$ & $\mathrm{V}$ & $\mathrm{V}$ & $\mathrm{V}$ & $\mathrm{V}$ & $\mathrm{V}$ & $\mathrm{V}$ & $\mathrm{V}$ & $\overline{\mathrm{V}}$ & $\mathrm{V}$ & $\overline{\mathrm{V}}$ & $\mathrm{V}$ & $\mathrm{V}$ & $\mathrm{V}$ & $\mathrm{V}$ & $\mathrm{V}$ & $\mathrm{V}$ & $\mathrm{V}$ & $\mathrm{V}$ & $\mathrm{V}$ & $\overline{\mathrm{V}}$ & $\mathrm{V}$ & $\mathrm{V}$ & $\mathrm{V}$ & $\mathrm{V}$ & $\overline{\mathrm{V}}$ & $\mathrm{V}$ & $\mathrm{V}$ & 12 \\
\hline \begin{tabular}{|l|}
$1998: 7$ \\
\end{tabular} & $\mathrm{~V}$ & $\mathrm{~V}$ & $\mathrm{~V}$ & $\mathrm{~V}$ & $\mathrm{~V}$ & $\mathrm{~V}$ & $\mathrm{~V}$ & $\mathrm{~V}$ & $\nabla$ & $\mathrm{V}$ & $\mathrm{V}$ & $\mathrm{V}$ & $\mathrm{V}$ & $\mathrm{V}$ & $\mathrm{V}$ & $\mathrm{V}$ & $\mathrm{V}$ & $\mathrm{V}$ & $\mathrm{V}$ & $\mathrm{V}$ & $\mathrm{V}$ & $\mathrm{V}$ & $\mathrm{V}$ & $\mathrm{V}$ & $\mathrm{V}$ & $\mathrm{V}$ & $\mathrm{V}$ & $\mathrm{V}$ & $\mathrm{V}$ & \begin{tabular}{|l|}
$\mathrm{V}$ \\
\end{tabular} & $\mathrm{V}$ \\
\hline 1998:8 & $\mathrm{V}$ & $\mathrm{V}$ & $\mathrm{V}$ & $\mathrm{V}$ & $\mathrm{V}$ & $\mathrm{V}$ & $\mathrm{V}$ & $\mathrm{V}$ & $\mathrm{V}$ & $\mathrm{V}$ & $\mathrm{V}$ & $\mathrm{V}$ & 11 & $\mathrm{~V}$ & $\mathrm{~V}$ & $\mathrm{~V}$ & $\mathrm{~V}$ & $\mathrm{~V}$ & $\mathrm{~V}$ & $\mathrm{~V}$ & 11 & $\mathrm{~V}$ & $\mathrm{~V}$ & $\mathrm{~V}$ & $\mathrm{~V}$ & $\mathrm{~V}$ & $\mathrm{~V}$ & $\mathrm{~V}$ & $\mathrm{~V}$ & $\mathrm{~V}$ & $\mathrm{~V}$ \\
\hline 1998:9 & $\mathrm{V}$ & $\mathrm{V}$ & $\mathrm{V}$ & $\mathrm{V}$ & $\mathrm{V}$ & $\mathrm{V}$ & $\mathrm{V}$ & $\mathrm{V}$ & $\mathrm{V}$ & $\mathrm{V}$ & $\mathrm{V}$ & $\mathrm{V}$ & $\mathrm{V}$ & $\mathrm{V}$ & $\mathrm{V}$ & $\mathrm{V}$ & $\mathrm{V}$ & $\mathrm{V}$ & $\mathrm{V}$ & $\mathrm{V}$ & $\mathrm{V}$ & $\mathrm{V}$ & $\mathrm{V}$ & $\mathrm{V}$ & $\mathrm{V}$ & $\mathrm{V}$ & $\mathrm{V}$ & $\mathrm{V}$ & $\mathrm{V}$ & $\mathrm{V}$ & $\underline{12}$ \\
\hline
\end{tabular}

number of days passed : 331

number of data input errors : 0

number of processing errors occured : 0

number of test failed errors occured : 41

number of days processed : 372

\section{Error number description :}

- $\mathrm{V}$ : verified ok

\section{processing errors :}

- $\quad-3$ : error in getnoonelev4day while calculating noonelevation

- -2 : error in getGC0day while calculating extraterrestial value

- $\quad-1$ : error in getGC4day while calculating models value

data input errors :

- 1 : sort of failed : no Value was given for this day

test failed errors :

- 10 : failed : exceeds calculated extraterrestial value

- 11 : failed : exceeds model's Gc value by more than $110 \%$

- 12 : failed : too small against extraterrestial value

- 21 : sol. elev. $<2$ [deg] \& extraterr. $>=2.78$, failed : exeeds model's Gc value by more than $200 \%$

- 22 : sol. elev. $<2$ [deg] \& extraterr. $>=2.78$, failed : too small against extraterrestial value

- 23 : sol. elev. $<2$ [deg] \& extraterr. $><2.78$, failed : exeeds $27.78>$

- 24 : sol. elev. $<2$ [deg] \& extraterr. $><2.78$, failed : below zero $>$ 